九州大学学術情報リポジトリ

Kyushu University Institutional Repository

\title{
Artist as Disciple: Miyajima Tatsuo and Sōka Gakkai
}

Woolsey, Jeremy

Tokyo University of the Arts, Graduate School of Global Arts

https://doi.org/10.5109/2231580

出版情報: Journal of Asian Humanities at Kyushu University. 4, pp.39-55, 2019-03. Kyushu University, School of Letters, Graduate School of Humanities, Faculty of Humanities バージョン:

権利関係 : 


\title{
Artist as Disciple: Miyajima Tatsuo and Sōka Gakkai
}

\author{
JEREMY WOOLSEY
}

$\mathbf{M}$

IYAJIMA Tatsuo 宮島達男 (b. 1957) is a Japanese artist known for his sprawling installations of digital light-emitting diode (LED) counters, which he calls "gadgets." Each gadget counts down from nine to one at a distinct, preset, or computer-determined speed, before resetting during a moment of darkness (in lieu of displaying zero); when placed together, they form a twinkling network that he likens to the interaction of individual lives passing in and out of history, or, on a macro scale, the creation and destruction of worlds. ${ }^{1}$ In addition to these installations, the artist has experimented with performance and socially engaged art, most notably through his Revive Time: Kaki Tree Project tree-planting series, which started in 1996 and continues to this day. Miyajima graduated with an MA from the Tokyo University of the Arts, Graduate School of Fine Arts (Tōkyō Geijutsu Daigaku Daigakuin Bijutsu Kenkyūka 東京藝術大学大学院

I would like to thank Chelsea Foxwell, Levi McLaughlin, and James Dorsey for their thoughtful feedback. The suggestions of an anonymous reader also greatly helped to improve this article.

1 "Each unit represents one human or world, and these interrelate to form a greater space: society or the universe." Miyajima, Miyajima Tatsuo kaitai shinsho, p. 136. I clarify here that there are many different versions of these LED counters: some are analog, some count up, and some show two digits instead of one. In addition, the size of these counters varies greatly from work to work.
美術研究科) in 1986, and worked as an editor before making his international debut in the 1988 Venice Biennale with Sea of Time (figure 1). ${ }^{2}$ He also participated in the influential 1989-1990 Against Nature exhibition, which introduced his work to a general American audience. $^{3}$

Although his oeuvre's visual appeal and philosophical commentary on time and life has garnered much attention, one aspect of Miyajima's career has been for the most part consigned to the shadows in critical reception: his relationship to Sōka Gakkai 創価学会, a Japanese new religion (shinkō shūkyō 新興宗教) based on the teachings of Nichiren 日蓮 Buddhism. ${ }^{4}$ This ten-

2 Figure 1 and other images used herein may be found on the artist's website: https://tatsuomiyajima.com/.

3 The exhibition traveled to a number of major US cities, including San Francisco, New York City, and Houston, among others. See https://listart.mit.edu/exhibitions/against-nature-japaneseart-eighties.

4 Sōka Gakkai was established in the 1930 s by the educator Makiguchi Tsunesaburō 牧口常三郎 (1871-1944) as a study group before growing into a religion informed by the teachings of Nichiren Buddhism, particularly the Nichiren Shōshū 日蓮正宗 sect. It grew rapidly after the conclusion of World War II under the leadership of Toda Jōsei 戸田城聖 (1900-1958), while also advancing into the Japanese political world with the formation of the Kōmeitō 公明党 party in 1964. This party attracted intense criticism for its perceived threat to the democratic ideals of postwar Japan, particularly the separation of religion and state. 


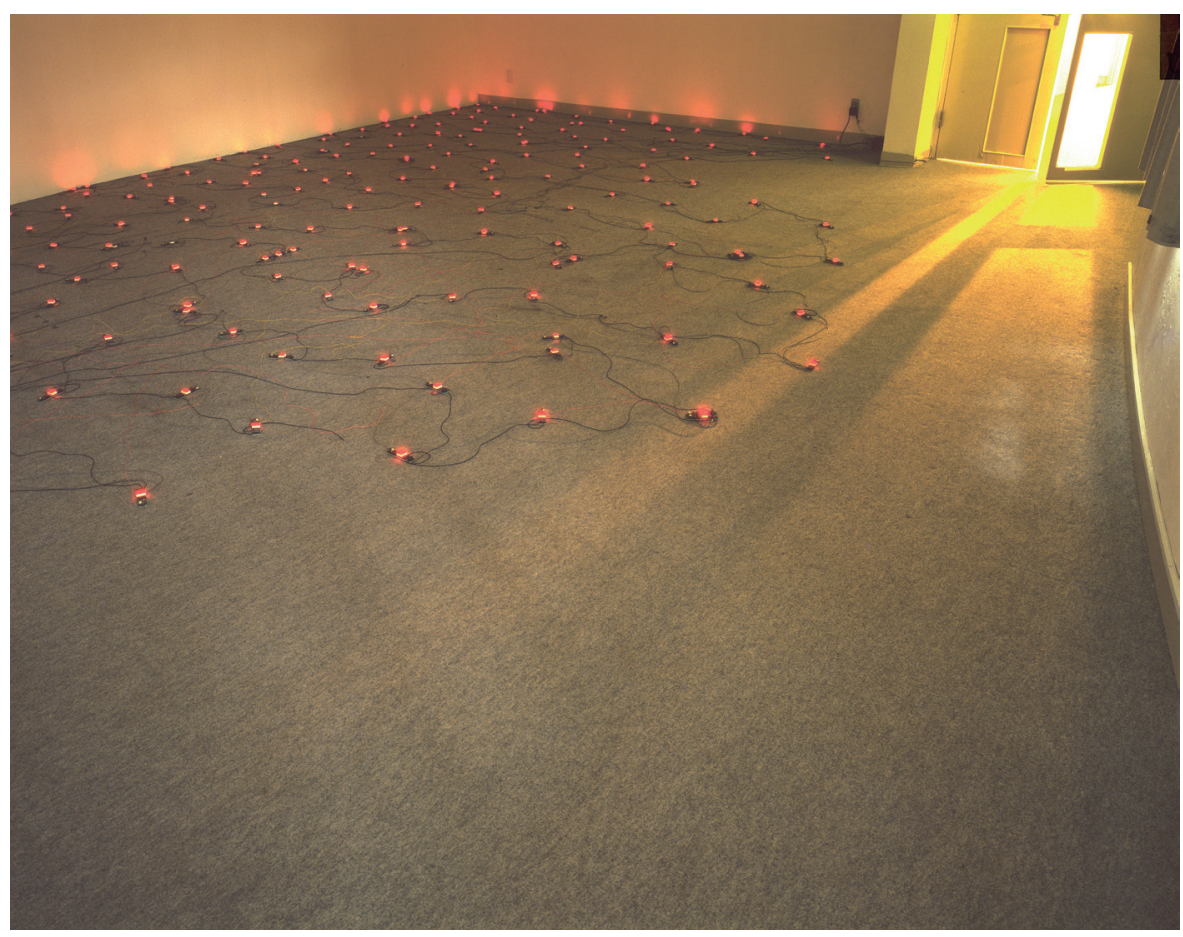

Figure 1. Miyajima Tatsuo. Sea of Time. 1988. Light-emitting diode (LED), integrated circuit (IC), electric wire. Installation view at Hara Museum of Contemporary Art, Tokyo. H 700 cm, W 700 cm, D 2.5 cm. Sitespecific installation. Photograph by Hirose Tadashi. Permission of the artist.

dency to downplay the artist's faith is no surprise given the increased stigmatization of so-called new religions following the 1995 Tokyo subway sarin attack perpetrated by the religious group Aum Shinrikyō オウム真 理教. Furthermore, Miyajima’s religious affiliation remains difficult to account for in a highly secularized contemporary art world. ${ }^{5}$ In response to these trends, this article seeks to illustrate how Miyajima subverts the supposed binary between individual and organizational expression in contemporary art through his affiliation with Sōka Gakkai. It represents Miyajima’s artistic career as inseparable from his religious practice,

Today it is no longer directly overseen by Sōka Gakkai but the two remain closely linked. Ikeda Daisaku 池田大作 (b. 1928) took over leadership of the group in 1960 and continues to lead de facto as the "honorary president." The author is not affiliated with Sōka Gakkai.

5 Here I refer to the dominant understanding of the development of modern art (and by extension, contemporary art) as the ascendance of secular, individual expression over religious-allegorical, collective forms of expression. See, for example, Groys, Art Power, p. 2; Krauss, The Originality of the Avant-Garde and Other Modernist Myths, p. 12. one which asserts communal bonds over individual achievement, and in effect offers a unique commentary on the modern myth of the autonomous artist.

My methodology differs from past studies of Miyajima in that I focus primarily on the ways that Miyajima understands his own work and seeks to defend it through writing, rather than the reception of his work among critics. The conceptual artist Joseph Kosuth's (b. 1945) essay "Art After Philosophy" plays an important role in this approach. ${ }^{6}$ In this essay, Kosuth describes how the concept behind the artwork is the key to participating in the art experience:

6 The art critic Chiba Shigeo 千葉成夫 has criticized the use of Western models of conceptual art in the Japanese context, asserting that conceptual art reduced art to the dimension of language and thus allowed anything to be called "art," while Japanese conceptualists such as Matsuzawa Yutaka 松澤宥 (19222006) attempted to "return" art to a state beyond art (to take art out of art) and restore it with the world and universe (sekai 世界, uchū 宇宙). I see Miyajima's use of language-based concepts, however, to be more in line with "Western" conceptualism and this is why, in part, I reference Kosuth here. Chiba, Gendai bijutsu itsudatsushi, pp. 107-10. 
Advance information about the concept of art and about an artist's concepts is necessary to the appreciation and understanding of contemporary art. Any and all of the physical attributes (qualities) of contemporary works, if considered separately and/ or specifically, are irrelevant to the art concept. The art concept ... must be considered in its whole. ${ }^{7}$

Joseph Kosuth's understanding of art is tautological: he theorized that a work of art "[provides] no information what-so-ever about any matter of fact.... A work of art is a tautology in that it is a presentation of the artist's intention, that is, he [sic] is saying that a particular work of art is art, which means, is a definition of art." As such, art, for Kosuth, primarily refers back to itself as a collective body of statements about "art." Benjamin Buchloh has criticized him on this count for repeating the modernist tendency of separating art from the economic and institutional systems that support it, as well as "[foregrounding] intentional declaration over contextualization." 9 While I agree that the artist cannot dictate how his or her art is received, and that art must always be evaluated in relation to its institutional context, it should not be overlooked that the knowledge of the conceptual basis for an artist's work is paramount to its critical assessment and contextualization in art history. ${ }^{10}$

Significantly, Miyajima Tatsuo has expressed a similar understanding of his artistic process to that of Kosuth's definition. In an interview he mentions: "I produce all my work aware of the path I've traveled and the different routes of thought I've taken. I haven't shown anything to date that doesn't derive from these. Actually, I've created unrelated work, but I just don't display it." "11 Consequently, I seek to understand his production in relation to this "path," in other words, the concep-

7 Kosuth, Art after Philosophy and After: Collected Writings, 1966-1990, p. 23

8 Ibid., p. 20

9 Buchloh, "Conceptual Art 1962-1969," p. 126

10 Boris Groys argues that the artwork, with the development of conceptual art in the 1960s, became a "poetic instrument of communication rather than an object of contemplation." Groys, In the Flow, p. 130.

11 Miyajima, Miyajima Tatsuo kaitai shinsho, p. 62. Here I do not mean to imply that the concept completely fixes Miyajima's process. He has characterized his production as a dialogue between the ongoing development of his concept and the physical act of creation. Instead, I draw attention to the artist's careful presentation of his work to reflect a unified progression. tual underpinnings of his work, even if this approach is but one of many possible ways to interpret his art. As the total art concept is not limited to the artworks alone, I also analyze the persona Miyajima has created through his writing and interviews. Going forward, I divide my assessment of the artist's concept and career into two sections that mirror the two central aspects of Sōka Gakkai doctrine and practice: Nichiren Buddhism and the worship of Sōka Gakkai's honorary president Ikeda Daisaku 池田大作 (b. 1928). In the first half I analyze three representative Miyajima works and their relationship to the Lotus Sutra and Nichiren Buddhism, the basis of Sōka Gakkai doctrine. In the second, I transition to an analysis of Miyajima's understanding of the ideal artist, arguing that it can be understood as a mimetic representation of Ikeda Daisaku in the art world. ${ }^{12}$

\section{Nichiren Buddhism and the Lotus Sutra in Miyajima's Work}

Miyajima's art is often labeled "Buddhist," but little critical work has been put into looking beyond this vaguely Oriental notion of a monolithic "Eastern" entity to understand the specific tradition of Buddhism that informs his work. Art critics in printed media have been especially negligent in assessing Miyajima's work, incorrectly attributing content to "Miyajima's Zen interests,"13 for example, or attaching essentializing remarks related to the artist's nationality: "By employing alarm-clock technology to say deep Buddhist things about the relentless passage of time and the unstoppable rhythms of life, Miyajima is, of course, being fully Japanese." ${ }^{14}$ Academic literature has at times emphasized the centrality of the Mahāyāna Buddhist doctrine of emptiness ( $k \bar{u}$ 空) in the artist's work; closer inspection of his life reveals it to be far more indebted to Nichiren Buddhism, especially the Nichiren Shōshū

\footnotetext{
12 Here I draw on terminology suggested by the religious studies scholar Levi McLaughlin, who argues that Sōka Gakkai resembles a mimetic nation built on both Buddhist practice and worship of the current honorary president Ikeda Daisaku. McLaughlin, "Sōka Gakkai in Japan," p. 297.

13 Bywater, "Mediarena Govett-Brewster Art Gallery," p. 239.

14 Waldemar Januszczak, "Countdown conundrum: How can a room of flashing LED numerals be sentimental?" The Guardian, 2009.11.29.
} 


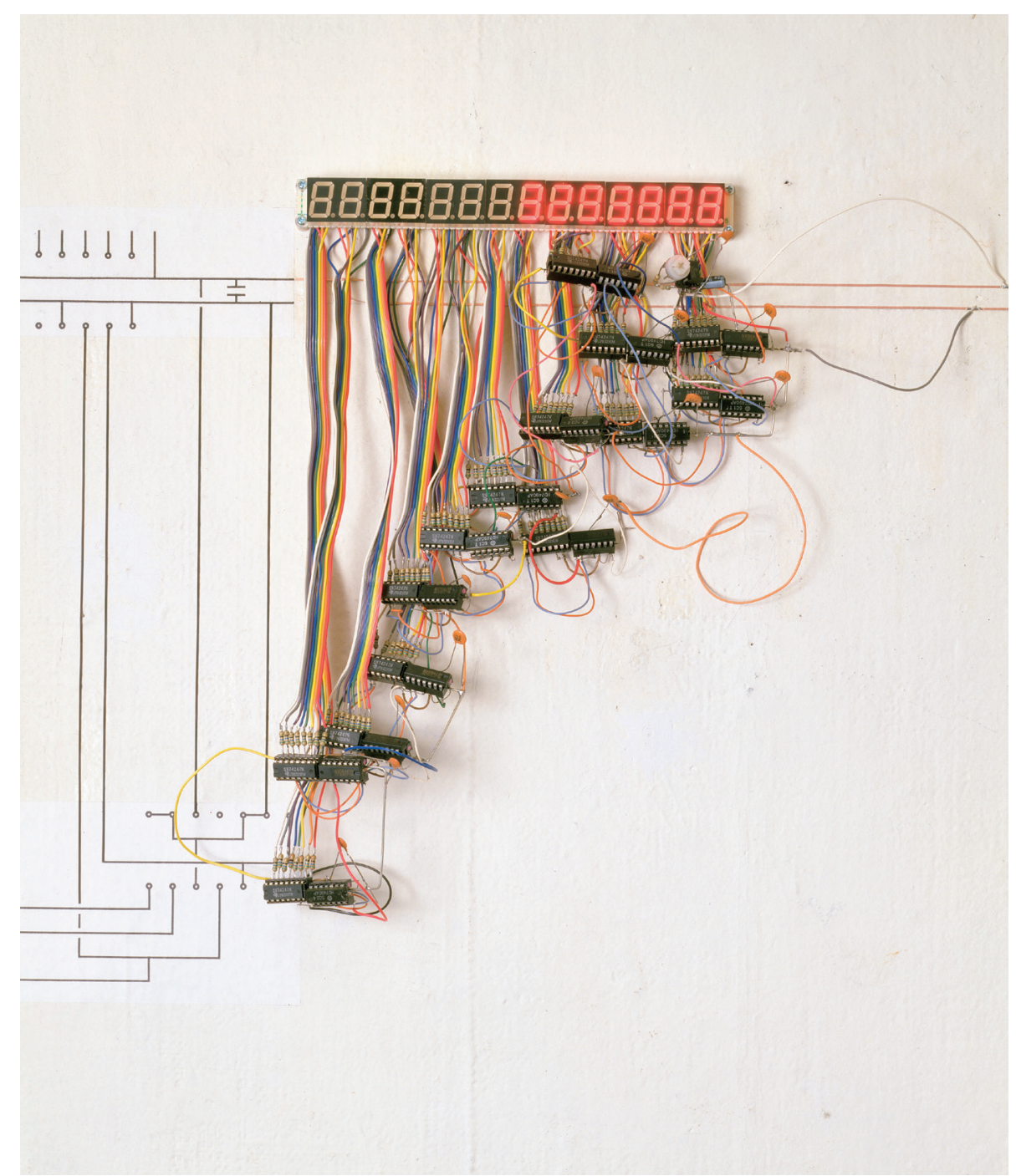

Figure 2. Miyajima Tatsuo. Clock for 300 Thousand Years. 1987. LED, IC, electric wire, line tape, etc. Installation view at Runami Gallery. H $173 \mathrm{~cm}$, W 630 cm, D 5 cm. Site-specific installation. Photograph by Hirose Tadashi. Permission of the artist.

日蓮正宗 sect and today’s Sōka Gakkai. ${ }^{15}$

The artist himself has been highly strategic in explaining his work's relation to Buddhism, in part to avoid being contained by Orientalist tropes:

15 See De Jongh, "Time in the Art of Roman Opalka, Tatsuo Miyajima, and Rene Rietmeyer," p. 102; Tzou, "Cultural-Specific and International Influences," p. 258. Shwu-Huoy Tzou briefly touches on the artist's relation with Sōka Gakkai; here I address its practices and doctrine more rigorously.

At the time when I made the three concepts [1987; explained in the following section], the West only recognized meditation and Zen as Eastern wisdom and this didn't really leave the territory of Orientalism, of fetishizing outside culture. For this reason, I avoided Buddhist rhetoric and tried to get at something deeper about what they were seeing in a language that would get across to them. ${ }^{16}$ 
Of course, Miyajima is just one of many Japanese artists who employ Buddhist motifs in their work. In the postwar period alone, such artists range from Shiraga Kazuo 白髪一雄 (1924-2008)-who trained at the Tendai 天台 sect's head temple Enryakuji 延暦 寺 starting in $1971^{17}$-and Matsuzawa Yutaka 松澤宥 (1922-2006), to Mori Mariko 森万里子 (b. 1967) and Murakami Takashi 村上隆 (b. 1962) in more recent years. ${ }^{18}$ Indeed, there is no way to convincingly connect the diverse body of Japanese artists who either practice, reference or have been inspired by Japanese Buddhism, to say nothing of the international context. To differentiate Miyajima from the bulk of these artists, I emphasize his underlying art concept as a direct and unified representation of Sōka Gakkai doctrine and practicenot as a unique synthesis of Buddhist themes and personal interests that attests to the artist's originality. ${ }^{19}$

A comparison with Matsuzawa Yutaka proves informative here, as this artist's work was also steeped in Buddhism at a conceptual level. The art historian Reiko Tomii characterizes Matsuzawa's relationship to religion as follows:

Despite Matsuzawa's heavy reliance on Exoteric and Esoteric Buddhism, his conceptualism was universalist. Aiming to reach out to all humans in a nonsectarian language, he standardized the

17 Art historian Namiko Kunimoto characterizes Shiraga's period of training as "a continuation of his ceaseless testing himself as an artist and a man." Here we see an example of the modernist tradition of equating religion with a heroic, personal quest. Kunimoto, "The Buddhist Hero," p. 76.

18 The very notion of "Buddhist fine art" contains an inherent contradiction. Patricia J. Graham characterizes contemporary Japanese Buddhist art as being primarily divided between two factions: "Monks and lay practitioners associated with [Buddhism's] traditional institutions, and individuals [fine artists] inspired by Buddhist philosophy as propagated by secular scholars." Graham, Faith and Power in Japanese Buddhist Art, 1600-2005, p. 251. This divide occurred in tandem with the rise of a hierarchy of forms that placed fine arts (bijutsu 美術) above technical arts (kōgei 工芸). Traditional Buddhist crafts were generally classified as the latter. On the rise of this hierarchy of forms, see Kinoshita, Bijutsu to iu misemono, pp. 29-49.

19 The tendency for artists and critics alike to downplay or disregard religious affiliation reflects the influence of the literary group Shirakaba-ha 白樺派 on the development of modern art in Japan. Its members were not affiliated with organized religions; instead, they were connoisseurs of religion, synthesizing many creeds into a universal, non-sectarian understanding of "inner life" (内 部生命 naibuseimei). See Kuno and Tsurumi, Gendai Nihon no shisō, pp. 7-8; Kitazawa, Kishida Ryūsei to Taishō avangyarudo, pp. 59-67.
Eastern wisdom and used the sharable and communicative form of art. Moreover, his sources were not just Eastern and ancient; he scoured the peaks and valleys of knowledge to identify ways to see the invisible in its visible states and codified the method as kannen..$^{20}$

Matsuzawa's art concept can hence be likened to an elaborate bricolage: his interest in exoteric and esoteric Buddhist practices and doctrine, including, for example, the Pure Land (Jōdo 浄土) tradition's

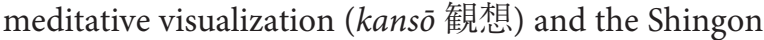
真言 tradition's moon meditation (gachirinkan 月輪 観), merged with parapsychology and contemporary science to form a conceptual base for his desire to "vanish the object" as well as create "non-sensory" painting. In short, he creatively synthesized the doctrines of various Buddhist traditions with many other forms of knowledge to further his personal artistic goals. I would argue that this is the dominant paradigm for understanding religion in art today-the assumption that religious motifs somehow pass through the black box of individual interest and interpretation before being materialized in the artwork. Significantly, Miyajima's art necessitates a departure from this paradigm - it represents not the endless customization of religious themes or "spiritual" interests, but concrete religious affiliation with Sōka Gakkai and an attempt to portray a unified system of belief and practice through art. In the following sections, I will analyze three representative works of Miyajima-Clock for 300 Thousand Years (1987), Mega Death (1999), and HOTO (2008) - and their relationship to the Lotus Sutra and Nichiren Buddhism. The latter form the basis of Sōka Gakkai doctrine and consequently inform Miyajima's personal life as well as his artistic production.

\section{- The Lotus Sutra and Clock for 300 Thousand Years}

In 1987, Miyajima produced his first artwork showcasing his now signature style of LED counters, entitled Clock for 300 Thousand Years (figure 2). ${ }^{21}$ The artist ex-

\footnotetext{
20 Tomii, Radicalism in the Wilderness, p. 75.

21 This project featured a simple design-a 14-digit monitor that would (could) count up to 300,000 years.
} 
plains the concept behind this piece in his 2017 book Theories of Art (Geijutsuron 芸術論):

\begin{abstract}
In the chapter "The Life Span of the Tathāgata" [nyorai juryōbon 如来寿量品] of the Lotus Sutra, the historical Buddha, thought to have appeared in India and awakened under a bodhi tree, is revealed to have existed in the infinite past [kuon 久遠]an incalculable 500 dust-particle kalpas [gohyaku jinten gō 五百塵点劫] ago. Our minds can't conceive of a timescale this vast. My 1987 Clock for 300 Thousand Years was created to show this concept of eternity [eien 永遠].22
\end{abstract}

This description quotes the doctrine of the Tendai and Nichiren sects, namely the partitioning of the Lotus Sutra into shakumon 迹門 and honmon 本門 sections. While the shakumon describes the truth of the One-Buddha vehicle (ichibutsujō 一仏乗), i.e., the ability of all to obtain buddhahood, the honmon contains an even deeper truth (particularly from the perspective of the Nichiren sect)-namely, that the Buddha did not really die at the age of eighty but awakened in the close to eternal past as the primordial Saakyamuni Buddha and continues to return as a bodhisattva to preach the ultimate truth, that is, the Lotus Sutra. What gives meaning to the endless progression of time in Miyajima's clock is this honmon section of the Lotus Sutra. This is clear enough from the artist's above description, and is further expanded upon in the following paragraph:

What I was trying to see in [Clock for 300 Thousand Years] was "now," constantly changing from moment to moment. Another name for the Buddha一nyorai 如来一is a translation of the Sanskrit term Tathāgata.... This word contains the meaning "he who comes from moment to moment" [nyonyo toshite kitarishi mono 如如として来たりし者]. ${ }^{23}$

Judging from these descriptions, the concept behind this work refers to a sense of purposeful time as described in the Lotus Sutra: From moment to moment,

22 Miyajima, Geijutsuron, p. 29. There are many definitions of a "kalpa" in Buddhism, but it can be generally understood as a cyclical unit of time that contains the creation and destruction of the world or universe.

23 Ibid., p. 29. one continues to maintain a relationship with the historical Buddha and the primordial Buddha on the way to one's own buddhahood, especially through the practice of chanting the title (daimoku 題目) of the Lotus Sutra as is advocated in the Nichiren tradition. ${ }^{24}$

Here I want to contrast this vision of time with the works of two other influential conceptualists: On Kawara (1932-2014) and the abovementioned Matsuzawa Yutaka. Kawara is known for his date paintings, and postcard and telegram art. ${ }^{25}$ Though he began his career as a painter as part of the social realism movement in postwar Japan, Kawara left Japan in 1959 and subsequently spent the rest of his life based in New York City, traveling all over the world while creating a diverse body of conceptual art. ${ }^{26}$ Matsuzawa is famous for having a mystical epiphany that compelled him to "vanish the object" through his art, and represented the vanguard of conceptualist practices in Japan during the 1960 os and 1970s. The differences in the three artists' attitudes and methods become most apparent in a comparison of Kawara's One Million Years project (1970-1971, 1980-1998) and Matsuzawa Yutaka's 1970 My Own Death with Miyajima's Clock for 300 Thousand Years. In One Million Years, Kawara created two books (One Million Years [Past] and One Million Years [Future]) that collectively represent the passage of time in typed calendar years from " 999,031 B.C. to 1969 A.D." and "1981 A.D. to 1,001,980 A.D." The artist dedicated Past to "all those who have lived and died" and Future

24 The Lotus Sutra is a central part of the monk Nichiren's 日蓮 (1222-1282) thought as well as Sōka Gakkai's doctrine and practice. Nichiren, in accordance with the Tendai sect's interpretation (Nichiren originally trained under this sect), put principle emphasis on the honmon, and went so far as to advocate that chanting the Lotus Sutra's title alone (namumyōhōrengekyō 南無妙法蓮華 経) was enough to realize the mind of the primordial Śākyamuni Buddha inside a practitioner. This practice is known as daimoku. Asai, "The 'Lotus Sutra' as the Core of Japanese Buddhism," p. 61

25 See Woo, "On Kawara's 'Date Paintings': Series of Horror and Boredom," pp. 63-68, for a detailed description of his process. The "date painting" series, which began in 1966, was completed through Kawara's death. He painted each day's date in white on a monochrome surface and destroyed the painting if it was not completed by the end of that day, while keeping a journal, and occasionally attaching newspaper clippings.

26 Miyajima has mentioned Kawara's influence on his art: "At the time [1987], I liked On Kawara. I really liked his work. His concepts were clear, and more than that his works were good. I felt them to be precious. He's called a conceptual artist, but if the work that expresses the concept isn't beautiful in itself, then it's not going to be remembered." Miyajima, Miyajima Tatsuo kaitai shinsho, p. 73. 
to "the last one," evoking a sense of the empty, meaningless passage of time and the possibility of human extinction. Matsuzawa's piece is even simpler in design: just a sentence inscribed on a placard that reads (in Japanese and English):

When you go calmly across this room, [let] go my own death across your mind in a flash of lightning, that is my future genuine death and is similar not only to your future death but to the past hundred hundred millions of human beings' deaths and also to future thousand trillions of human beings. ${ }^{27}$

On the difference between these two works, Reiko Tomii notes that "Matsuzawa's time can be meditated by the viewer in the stretch of time required to pass through a gallery, while Kawara's time must be experienced in a prolonged manner through reading it or listening to its recitation." ${ }^{28}$ I would add here that Miyajima's clock, which automatically ticks away time and provides a more robust, independent sense of physical existence than Kawara or Matsuzawa's text-based works, operates whether the viewer is present or not-its concept depends less on interaction with the viewer than the other two works. Put another way, it signifies an independent law or process at work through the passage of time, one that began in the infinite past - what the artist in this case calls kuon.

While all three pieces focus on numerical scales or timescales that utterly relativize the importance of an individual's existence, Miyajima's clearly draws on a cosmological view based on Nichiren's understanding of the Lotus Sutra. As a depiction of kuon, it contains the positive connotation of salvation, of the gradual awakening of all beings aided by the endless return of the Sākyamuni Buddha as a bodhisattva (this aspect of salvation differs decisively from the role of time in Kawara's and Matsuzawa's works). It is no coincidence that this specific reading of the Lotus Sutra, an important doctrinal aspect of Nichiren Buddhism and Sōka Gakkai, represents the conceptual base of the work, one not so much creatively synthesized or altered by the artist at the conceptual level as simply given poetic, concrete shape as a clock endlessly accumulating time.

\footnotetext{
27 This is the original text used for the work. See Tomii, Radicalism in the Wilderness, p. 148

28 Ibid., p. 191.
}

\section{- Mega Death and Toda Jōsei}

One of Miyajima's best-known works, Mega Death (figure 3), portrays a more cyclical vision of time than his early work Clock for 300 Hundred Thousand Years. This work comprises over 2,450 blue-light LED counters (in its iteration at the 1999 Venice Biennale) that flash, count, and disappear at random intervals; it is immersive in its scale and color. After roughly an hour elapses with more and more counters activating throughout, all counters suddenly extinguish and the room goes pitch black. Shortly after this dramatic rupture, the LEDs start up once more, and the blue light slowly gains strength - this cycle repeats endlessly. The artist uses these periods of absolute darkness as a metaphor to signal the atrocities of the twentieth century. ${ }^{29}$

Miyajima's art is often considered in relation to the "Buddhist" notion of reincarnation, and this piece would be a prime example as it works on two different levels - the constant "death" and "rebirth" of each individual LED counter as well as the periodic extinction of the entire system. Art historian Richard Dorment assesses the role of reincarnation in Miyajima's art as follows:

At the core of Miyajima's work is the belief that time is life itself. Only death brings an end to time - at least in Western thought. [Miyajima], as a Buddhist, believes in reincarnation. When each counter reaches the number nine, the numerical cycle begins anew. When one counter "dies" it leaves a void for a few moments before returning again..$^{30}$

The rupture of all "life" in Mega Death, and its subsequent return, provides a good opportunity to examine

29 "According to the calculation of Brzezinski, former national security advisor to Jimmy Carter, 167,000,000 lives have been lost in the events caused by human acts such as war, revolution and conflict in the 20th century. This figure, a terrifying number, equals to a [sic] total population of Italy, France and England of 1997. In a way, this century has been an era of 'Artificial Mega Death."' "Mega Death," https://tatsuomiyajima.com/workprojects/mega-death-3/.

30 Richard Dorment, "A little light in the darkness," The Daily Telegraph, 1997.7.12. I am in general agreement with Dorment's assessment, though one wishes that art critics would abandon the monolithic notion of "Buddhism": there are far too many interpretations of reincarnation inside the diverse religion to make such a categorical statement. 


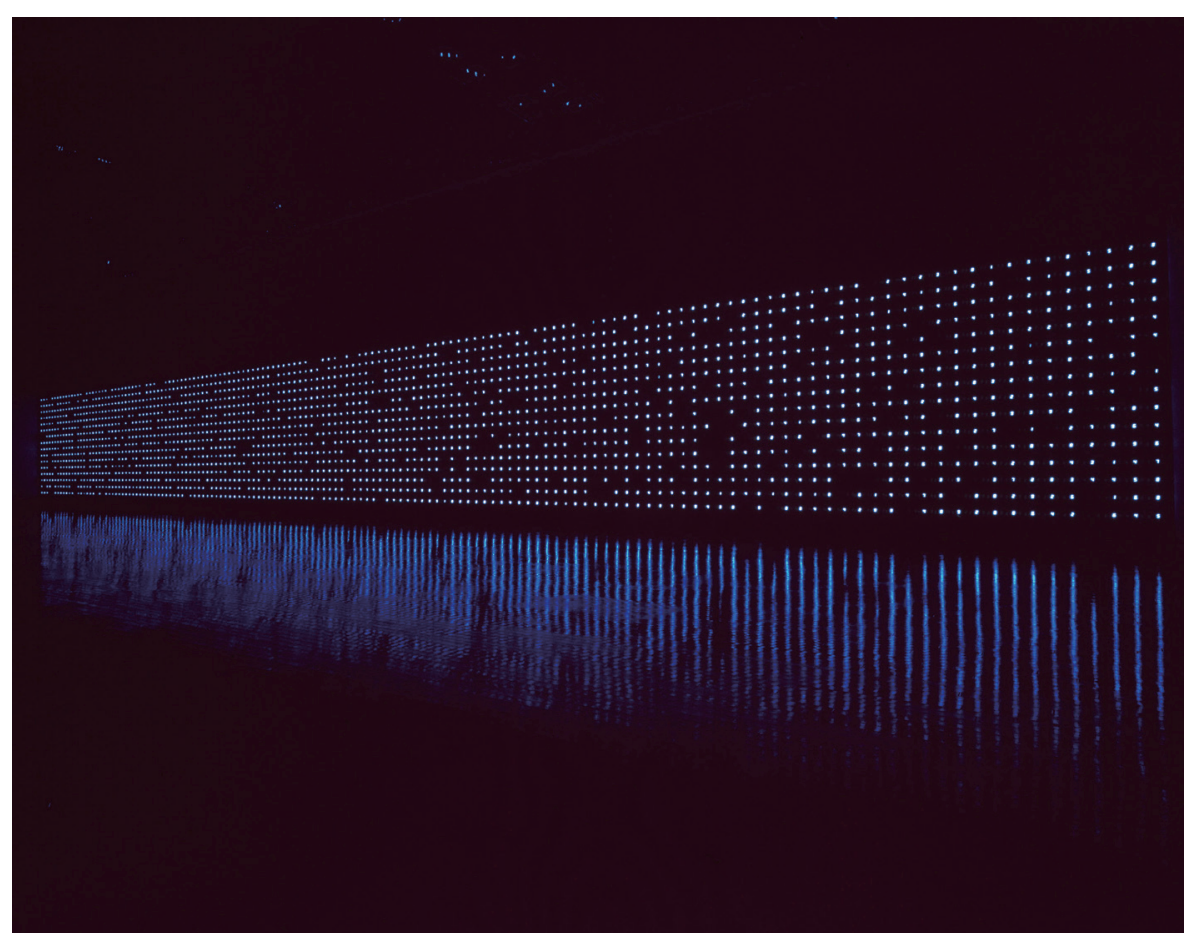

Figure 3. Miyajima Tatsuo. Mega Death. 1999/2016. LED, IC, electric wire, light sensor. Collection of Domus Foundation. Installation view at Tokyo Opera City Art Gallery. H $500 \mathrm{~cm}, \mathrm{~W} 3,400 \mathrm{~cm}, \mathrm{D} 1.8 \mathrm{~cm}$. Site-specific installation. Photograph by Ueno Norihiro. Permission of the artist.

the conceptual basis for reincarnation in Miyajima's work, which echoes Sōka Gakkai doctrine, and especially the thought of the group's second president, Toda Jōsei 戸田城聖 (1900-1958). To understand the constant change displayed through the resetting of the LED counters in the artist's installations, it is necessary to assess the "three concepts" that Miyajima claims are the basis of his project to date: "It keeps changing. It connects with everything. It continues forever." Here is the artist on the meaning of these concepts, which he determined in 1987:

What I wanted to communicate with this "it" was the brilliance of "human life," what is called Buddha-nature [busshō 仏性] in Buddhism. I was worried about how I should communicate this concept to others. If I said life [inochi 命] or Buddha-nature directly, these were already ... fixed images for people in the East, and, conversely, Westerners wouldn't understand them. ${ }^{31}$

Miyajima went on to use time as a means to express this "it" ("life" or "Buddha-nature"), but I want to emphasize here that this equation of life with the Buddha has a special significance in Sōka Gakkai doctrine through a mystical experience of Toda Jōsei-and later, its dramatic re-depiction in Ikeda Daisaku's Human Revolution (Ningen kakumei 人間革命) - which I will summarize briefly below. ${ }^{32}$

While imprisoned during the Asia-Pacific War along with Sōka Gakkai's founder, Makiguchi Tsunesaburō

31 Miyajima, Geijutsuron, pp. 13-14. Miyajima frequently and uncritically invokes the binary between the "West" and "East" in his writing.

32 See Shimada, Sōka Gakkai, pp. 43-46. As I will later describe, Ikeda's Human Revolution was a pivotal factor in Miyajima's conversion to Sōka Gakkai. This twelve-volume novel, originally published in 1965, depicts various individuals, including the abovementioned Toda Jōsei, who have conversion experiences and go on to improve their lives through the diligent practice of Nichiren Buddhism. 
牧口常三郎 (1871-1944), for refusing to enshrine State Shinto talismans, Toda Jōsei had a profound religious awakening that set the tone for his aggressive efforts to grow the organization after the war. Alternating between sessions of daimoku and slowly reading the entire Lotus Sutra in Chinese a total of three times, he experienced a revelation upon encountering the Thirty-four Negations, a passage that defines the Buddha in the Immeasurable Means Sutra (Muryōgikyō 無量義 経), essentially an introduction to the Lotus Sutra. He describes the content of his religious awakening in the novel Human Revolution (Ningen kakumei 人間革命) ${ }^{33}$ under the pen name Gan-san 嚴さん in the following ecstatic outburst: "The Buddha is an expression of life! He's not on the outside, but the inside of one's own life. No, he's on the outside, too! He's the single, unified substance of the life of the universe!"34

Here I want to focus on the language of this mystical experience, especially its conflation of the Buddha with life, as Miyajima begins his 2017 Theories of Art by quoting several of the Thirty-four Negations of the Innumerable Means Sutra ("his body is neither existing nor not existing, neither caused nor conditioned, neither square nor round, neither short nor long") that inspired Toda's experience. After doing so, he essentially reiterates Toda's rhetoric in the following passage of the book: "The 'he' in this text is the Buddha [hotoke 仏] or Buddha-nature [busshō 仏性], but in contemporary parlance, it might be easier to understand [him] as life [inochi 命]." ${ }_{35}$ Through his mystical experience, Toda also came to liken death to merely a brief period of sleep, supported by the eternal life of the Buddha ${ }^{36} \mathrm{Mi}$ yajima borrows this notion in his explanation of Mega Death, asserting that "in Buddhist Philosophy, the life of man is interpreted as the repetition of 'life' and 'death.' In other words, 'death' is not an end, but is similar to a [sic] sleep as a preparation for the 'next life." ${ }_{37}$ As per

33 This is a different novel than Ikeda Daisaku's twelve-volume series of the same name that I mention above.

34 “仏とは、生命の表現なんだ!外にあるものではなく、自分の命 にあるものだ!いや、外にもある! それは宇宙生命の一実体なん だ! ”Toda, Ningen kakumei, p. 238. The Japanese text is provided as it is a central tenet of Sōka Gakkai's theology and a reader of Japanese may find it important to reference.

35 Miyajima, Geijutsuron, pp. 13-14.

36 Shimazono, "Hotoke sunawachi seimei: Toda Jōsei," p. 315

37 Miyajima, "Mega Death," https://tatsuomiyajima.com/workprojects/mega-death-3/. Here Miyajima himself is not immune to the frustrating tendency to essentialize Buddhism, writing as if there was any such unified entity as "Buddhist philosophy." the language of Toda's religious awakening, this endless process of life and death is a manifestation of the Buddha's eternal life, that is "Buddha-nature" (or what the artist calls kuon in his Clock for 300 Hundred Thousand Years), reflecting a specific lineage of Buddhism with its origins in Japan through the Tendai sect, Nichiren sect, and, in modernity, Sōka Gakkai. Put another way, the constant change and flux in Miyajima's art, and especially the extinction of all life in Mega Death and its rebirth, paradoxically emerges as an illustration of this "Buddha-nature." The artist also uses the term "unchangingness" (jojju dha-nature" acts as a sort of phenomenological base for all existence: "The stable can only appear through the unstable." ${ }^{39}$ It should not be overlooked, however, that Miyajima's rhetoric reflects an understanding of life and the Buddha unified in Toda's mystical experience, one which remains an "integral part of [Sōka Gakkai's] doctrinal training." ${ }^{40}$ Miyajima's conceptual notion of time and related rhetoric closely follows the logic of this experience as it is portrayed in Sōka Gakkai doctrine; hence, Mega Death can be understood as the artist's attempt to create a visual representation of this doctrine through art.

\section{- The Treasure Tower}

The 2008 HOTO (figure 4) is the most concrete manifestation of the artist's religious devotion so far: a massive mirrored object covered in his signature LED counters (in all sizes, shapes, and styles), the work depicts a central scene in the Lotus Sutra. The artist describes the significance of the piece as follows: "My works until now were more indirect, but I don't have the leisure or time to do that anymore. I want to express concretely: 'This is a symbol of life!'”41 The treasure tower (hōtō 宝 塔) appears in the "Emergence of the Treasure Tower" chapter (kenhōtōhon 見宝塔品) of the Lotus Sutra. In this chapter, a jeweled stupa rises from the earth and hovers above the historical Buddha, who has finished

\footnotetext{
38 The term jōjū derives from the Mahāyāna Nirvana Sutra, which further develops the Lotus Sutra's concept of the One-Buddha vehicle, i.e., the reality that all beings can awaken, to assert that Buddha-nature is universal and everlasting.

39 Miyajima, Geijutsuron, p. 26.

40 McLaughlin, "Sōka Gakkai in Japan," p. 284.

41 Miyajima, Miyajima Tatsuo kaitai shinsho, p. 406.
} 


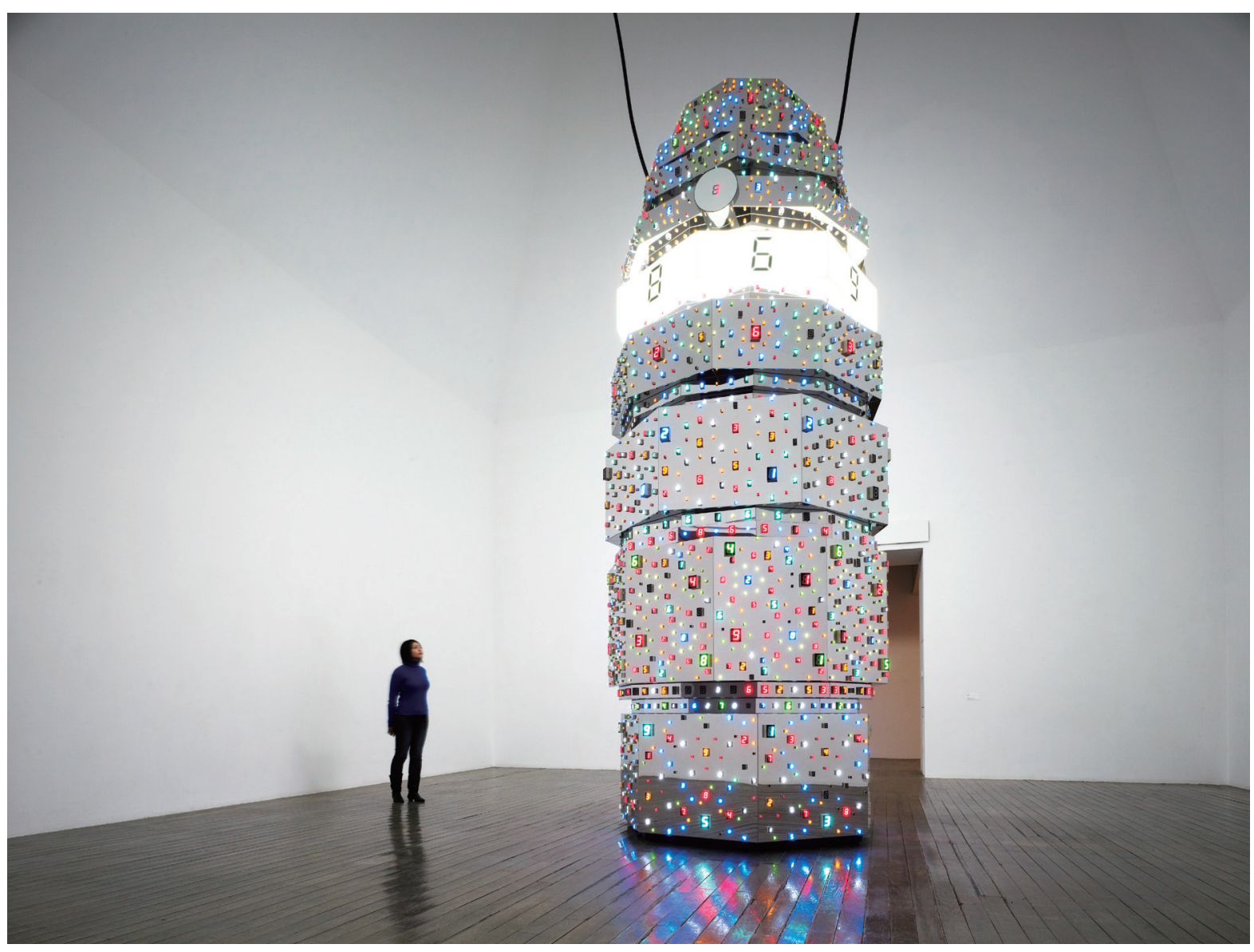

Figure 4. Miyajima Tatsuo. HOTO. 2008. LED, IC, electric wire, specular stainless steel, mirror glass, plexiglass. Collection of MGM Resorts International. Installation view at Art Tower Mito. H 549 cm, W $208 \mathrm{~cm}$. Photograph by Ano Daici. Permission of the artist.

teaching the One-Buddha vehicle (that is, the truth that all can awaken as bodhisattvas) and pledging the future enlightenment of many of his followers. Inside the pagoda is Tahō Nyorai 多宝如来, a buddha who promised in the infinite past to confirm the truth of the Lotus Sutra each time it is preached. The chapter is significant as it presages the second half (the honmon section) of the Lotus Sutra, namely the arrival of the Bodhisattvas of the Earth (Jiyu Bosatsu 地涌菩薩), and the revealing of the Buddha's eternal life in "The Life Span of the Tathāgata" chapter. ${ }^{42}$ It also has special meaning for Sōka Gakkai members because the scene where the Buddha sits face to face with Taho Nyorai in this tower is depicted in Nichiren's calligraphic

42 This is the chapter that Miyajima uses to ground the concept of his Clock for 300 Thousand Years, as I have mentioned above. mandala daigohonzon 大御本尊 (a replica of which is enshrined in Sōka Gakkai members' homes). ${ }^{43}$ The Soka Gakkai International website mentions that the tower in the Lotus Sutra represents "the unfathomable Buddha-nature inherent within the life of all people," which is consistent with the rhetoric that Miyajima uses to discuss the work; Ikeda himself asserts that this tower is the "grand and dignified original form of our lives." 44 While my above analysis of Clock for 300 Thousand Years and Mega Death argued that Miyajima's art can be read as a substantiation of Sōka Gakkai doctrine at the level of the concept, this work goes beyond the conceptual and presents a central image from the Lotus

\footnotetext{
43 McLaughlin, "Sōka Gakkai in Japan," p. 271.

44 "The Treasure Tower," http://www.sgi.org/about-us/buddhistconcepts/the-treasure-tower.html.
} 
Sutra. Its meaning is recognizable by name alone: any dedicated Sōka Gakkai practitioner could see the title and understand it as an allusion to the Lotus Sutra and the arrival of Tahō Nyorai. As such, it functions as an assertion of collective identity in the celebration of an important moment in the sutra..$^{45}$ This work represents Miyajima's most direct expression of affiliation to the organization to date and offers a compelling basis for trying to address this affiliation as a principle source (both at the conceptual and material levels) of his artistic production rather than decontextualizing or disregarding it as simply a matter of the artist's private life.

I have attempted here to give a brief example of the ways in which Sōka Gakkai doctrine supports Miyajima's work. I believe this consistent adherence to Sōka Gakkai teachings to be rare in the contemporary art world, wherein Buddhism is often invoked as a (fashionable, modernist) symbol of individuality over affiliation with an organized group. I argue that the art concept that underlies Miyajima's work comprises the tenets of Nichiren cosmology, and that the centrality of these tenets is too often overlooked in art criticism, where Miyajima's work is deemed "Buddhist" without reflection on the ambiguity of this term. The language invoked in Miyajima's explanations of his work - kuon, seimei, jojju, hōtō, etc. - is all part of a doctrinal system that represents the foundation of the religious group he belongs to, and thus signifies this belonging. In the following section, I shift toward the other axis of contemporary Sōka Gakkai doctrine and practice: worship of Ikeda Daisaku. If I have focused more on Miyajima's artistic production up to this point and how it relates to the Nichiren Buddhist doctrine of Sōka Gakkai, I now assess Miyajima's ideal image of the artist, which I argue is a mimetic representation of Ikeda Daisaku in the context of art.

\section{The Artist as a Disciple of Ikeda Daisaku}

The relationship between Miyajima Tatsuo and Ikeda Daisaku is often framed as a matter of Ikeda's "in-

\footnotetext{
45 Here my understanding of collective identity operates on two levels: ideally (speaking from the perspective of Miyajima) that of all humans, who recognize that they have the ability to become a buddha, and more specifically, that of Sōka Gakkai, whose members will be able to recognize this image as a central part of their doctrine.
}

fluence" on Miyajima. It is questionable, however, whether this word is appropriate in this context (in the sense that it is used in art writing, for example, "Pablo Picasso influenced Jackson Pollock"). ${ }^{46}$ Looking at Miyajima's art and his positioning himself as a "teacher" in the art world, it is clear that the relationship is far more complex than one of mere influence in the artistic sense. Instead, I want to look at what Clark Chilson has termed the importance of discipleship in the increasingly Ikeda Daisaku-centric doctrine of contemporary Sōka Gakkai: ${ }^{47}$

Those in the Gakkai today, following Ikeda's lead, create a self-conception of themselves as not simply Gakkai members or Nichiren Buddhists, but as disciples of a helpful and caring mentor. Because they conceive of themselves as disciples with Ikeda as their mentor, Gakkai members are more likely to act beyond their own narrow self interests and for the accomplishment of the Gakkai's goals..$^{48}$

Indeed, Miyajima is not an "autonomous," romantic, or avant-garde artist so much as he is a devoted disciple of Ikeda's. The mentor-disciple relation plays a key role in determining the ideal model of the "artist" and "human" that Miyajima posits in his writings and art. ${ }^{49}$ I argue that it reflects shiteifuni 師弟不二, an inseparable bond between mentor (Ikeda) and disciple in contemporary Sōka Gakkai's doctrine. Shiteifuni represents a constant striving to exemplify Ikeda's ethos through

46 "Miyajima has spoken at length about the profound influence of Buddhism on his practice. He cites the writings of Buddhist philosopher Daisaku Ikeda, a key figure within the Sōka Gakkai Buddhist organization, as particularly influential." Rachel Kent, "Tatsuo Miyajima: Connect with Everything," https:// tatsuomiyajima.com/texts/tatsuo-miyajima-connect-witheverything-essay-by-rachel-kent/.

47 Levi McLaughlin points out that this shift in the group's priorities from Nichiren Buddhism to worship of Ikeda ultimately caused its split from the Buddhist temple parent Nichiren Shōshū in 1991. McLaughlin, "Sōka Gakkai in Japan," pp. 298-300.

48 Chilson, "Cultivating Charisma," p. 70.

49 His 2017 book Theories of Art is dedicated to his two "teachers," Ikeda Daisaku and Enokura Kōji 榎倉康二 (1942-1995), an artist affiliated with the loosely organized group Mono-ha もの派: “I've never thought that I was a genius, and I've managed to stay this way thanks to two teachers: he who taught me the way of the human, Ikeda Daisaku, and he who taught me the way of art, Enokura Kōji" (p. 133). While Enokura was highly influential as a mentor to Miyajima, he was critical of the young artist's style, and as such did not encourage him to pursue a PhD at Tokyo University of the Arts. 
one's own life and work. As such, it becomes difficult to distinguish between mentor and disciple - the two come to mutually reinforce one another. Consequently, I seek to assess how Ikeda serves as a spiritual guide for Miyajima, as well as how this model of discipleship, of shiteifuni, in contemporary Sōka Gakkai radically challenges the notion of artistic autonomy and individuality that remains dominant in contemporary art.

\section{- Conversion}

Miyajima's (re)conversion to Sōka Gakkai (he was born a fukushi 福子, a child of Gakkai members) took place shortly before he entered art school. The following account is found in the book-length interview Unraveling Miyajima Tatsuo (Miyajima Tatsuo kaitai shinsho 宮島 達男解体新書). It is a typical example of conversion stories (taikendan 体験談) shared in group meetings, known as zadankai 座談会, to reinforce members' faith. ${ }^{\circ}$ In short, this is less a story of Miyajima's unique discovery of himself, or his style, so much as it represents just one of many members' paths to affiliation with the group, one that would provide the artist with the confidence to pursue a career in art.

By 1978, Miyajima had already twice failed his admission test to Tokyo University of the Arts and was losing hope of being admitted to the prestigious university and pursuing an art career. He had been creating all-over paintings-dripping paint on the canvas to emphasize its physicality-under the influence of American abstract-expressionist painters such as Jackson Pollock (1912-1956), Mark Rothko (1903-1970), and Barnett Newman (1905-1970), but was at an artistic impasse. This proved to be an existential question for the young artist, full of the desire to be recognized but lacking concrete direction. He retreated to his room and his increasingly antisocial behavior worried his parents. Around this time, as Miyajima tells the story, a neighbor gave him a copy of Ikeda Daisaku's Human Revolution. The artist's parents were already members of Sōka Gakkai, which was presided over directly by Ikeda at the time, but Miyajima had stubbornly refused to join the religion. Here he recounts his adolescent attitude: "I was very resistant to it [Sōka Gakkai]. I had my doubts about faith - I thought faith was too easy a way to im-

50 I thank Levi McLaughlin for alerting me to this similarity. prove one's life. Faith was for the weak, so I ignored it completely." ${ }^{1}$ Feeling lost at this juncture, Miyajima read Ikeda's twelve-volume work, which changed the course of his life, convincing him immediately to join Sōka Gakkai. By reading central portions of the Lotus Sutra and practicing daimoku daily, the artist slowly began to remake himself and his regimen for the university entrance exam:

I felt like I could see myself accurately ... it made complete sense what I had to do to improve. I was able to recognize that it was my fault that I had failed the exams, because my drawings weren't good.... By facing myself and pushing through, channels opened up to the outside-I began to hear outside voices. I listened to people's opinions and entered into a proper dialogue with others." ${ }_{52}$

Ultimately, he spent a year diligently improving his drawing skills and passed the admissions test, entering the Department of Painting at the Tokyo University of the Arts as an undergraduate in 1980. Reflecting on the process, he concludes with a representative remark: "My work and life rest on Ikeda Daisaku and my faith in Sōka Gakkai-these are my essence. If they weren't there, there would be no Miyajima Tatsuo, nor any of his work." 53

\section{- Ikeda’s Buddhist Humanism}

Miyajima's affiliation with Sōka Gakkai began shortly before he entered art school and continues to this day. Indeed, the artist goes far beyond private practice at home in his support of the group: he regularly contributes articles to Sōka Gakkai publications and campaigns publicly for bills sponsored by Kōmeitō (the political party originally directly overseen by Sōka Gakkai). ${ }^{54}$ The artist has also represented his local Sōka Gakkai community in the organization's bureaucracy

\footnotetext{
51 Miyajima, Miyajima Tatsuo kaitai shinsho, p. 385.

52 lbid., p. 389.

53 lbid., p. 393.

54 See, for example, his tribute to the organization's honorary president, Ikeda Daisaku: Miyajima, "Sekai ga motomeru ningen no tetsugaku," pp. 129-34, as well as a vivid account of his relations with Sōka Gakkai, "Hito toshite sosei shite kara hajimatta geijutsu e no michi," pp. 89-104.
} 
as a regional captain (chiiki buchō 地域部長). ${ }^{55}$ This involvement has attracted scrutiny from older artists, especially those on the left, which historically has aligned itself against Sōka Gakkai and Kōmeitō. ${ }^{56}$ Hori Kōsai 堀浩哉 (b. 1947), one of the representative members of the 1970s art group Bikyōtō 美共闘, an extension into art of the student movement in the late 1960s, for example, has criticized Miyajima for petitioning for a 2001 Kōmeitō-sponsored bill to make donations to art institutions tax-deductible, admonishing readers "not to be deceived by Kōmeitō and Miyajima Tatsuo." ${ }^{57}$ The artist Shirakawa Yoshio 白川昌生 (b. 1948) has called Miyajima Sōka Gakkai's "poster child" (kanbansakka 看板作家) in art..$^{58}$ It is hard to deny this claim, though whether one perceives it as an insult or not depends on one's already conceived opinion of Sōka Gakkai. Miyajima is the most famous contemporary artist working in Japan visibly associated with the group, and so inevitably takes on the role of its spokesman in matters artistic.

Putting aside the issue of how one feels about Ikeda Daisaku, I emphasize that the language Miyajima uses to describe his art, which he asserts is a tribute to "humanity" and "life," reflects shiteifuni. ${ }^{59}$ Once situated as borrowed from Ikeda, these terms take on new meaning as collective reference points, and perhaps more importantly than any independent meaning they might possess is the reality that they derive from such a hallowed figure (for Sōka Gakkai members) as Ikeda. Indeed, Miyajima has been very vocal in praising the accomplishments of Ikeda and his "Humanism," as such performing a central duty of Sōka Gakkai members:

55 See Miyajima, "Hito toshite sosei shite kara hajimatta geijutsu e no michi," p. 104

56 The Japanese Communist Party was fiercely critical of the group's growth in the 1960s, regarding its proselytization of blue-collar workers as disruptive to the organizing of the proletariat and awakening of class consciousness. Shimada, Sōka Gakkai, pp. 86-90.

57 Hori was not so much opposed to the content of the bill itself as to what he saw as Kōmeitō's use of the bill to gain support in upcoming elections. He also suggested that Miyajima's Kaki Tree Project (discussed below) was being funded by Sōka Gakkai (though the executive committee of this project vehemently denied this suggestion). Hori, "Kōmeitō to Miyajima Tatsuo ni wa damasareruna," p. 19.

58 "Hikosaka Naoyoshi-san, bijutsu hin kansatsu gakkai mēringu risuto de, mondai teiki! sono 2," http://www2a.biglobe. ne.jp/ yamaiku/honhon/lr/lr.hikosakao2.htm.

59 The subtitle of his Unraveling Miyajima Tatsuo, for example, reads "All for Human Existence," a phrase which seems overblown without further contextualization.
It's incredible that he's been recognized across the boundaries of language, thought, religion, culture, and ideology. Ikeda has raised the banner of $\mathrm{Hu}-$ manism [ningenshugi 人間主義] and transcended these barriers. If you go abroad, you can experience for yourself how the world's intellectuals seek out President Ikeda's thoughts and praise his actions. ${ }^{60}$

Ikeda's "Humanism" represents a fusion of Nichiren Buddhism and the writings of European and American writers and philosophers such as Henry Thoreau and Leo Tolstoy, with the thought of civil rights leaders including Mahatma Gandhi and Martin Luther King. ${ }^{61}$ It emphasizes an image of individuals ("humans") rising above sectarian differences and working to save themselves and improve their own lives through material gains and spiritual edification, while simultaneously helping others do the same. ${ }^{62}$ This lauding of individual agency and collective action deeply resonated with a young Miyajima when he read Ikeda's Human Revolution, and he has put it into practice through his art: it is clear that the artist's fixation on the "human" level should be read in light of his worship of Ikeda and his "Buddhist Humanism." ${ }^{3}$

Clark Chilson has evaluated the dynamic of the relationship between mentor and disciple in Sōka Gakkai, noting that "simple followers are not good disciples because they do not adequately seek ways to use their own individual talents to help realize their mentor's vision.... Good disciples protect and promote the mentor's vision, with which they identify." ${ }^{\prime 4}$ This would seem to reflect the position of Miyajima, who essentially translates Ikeda's ethos into the art world: "I'm nothing compared to my teacher [Ikeda], but for over

60 Miyajima Tatsuo "Sekai ga motomeru ningen no tetsugaku," p. 134.

61 McLaughlin, "Sōka Gakkai in Japan," p. 303.

62 "From the perspective of Buddhist humanism it is human beings themselves, rather than a higher power, who possess the ultimate wisdom about their condition. This view regards the individual as the pivotal force of change within the interdependent network of phenomena that comprises life. A fundamental change in the life of an individual, in other words, will affect the entire web of life." "Buddhist Humanism," http:// www.daisakuikeda.org/main/philos/buddhist/buddh-05.html.

63 The art historian Shwu-Huoy Tzou also correctly assesses the importance of Ikeda's thought in Miyajima's desire to "create 'a global unity' of humankind." Tzou, "Cultural-Specific and International Influences," p. 259.

64 Chilson, "Cultivating Charisma," p. 69. 
twenty years, I've believed that encouraging others is what a true human does." ${ }^{\prime 5}$ The importance of the mentor role in Miyajima's art is especially apparent in his Kaki Tree Project (which he started in 1996). His desire to activate viewers' belief in themselves and to serve as a "humanist" artist can be interpreted as a mimetic representation of Ikeda in the art world, and as such a form of religious practice, of aspiring to constantly strengthen his bond with his mentor by putting his principles into action.

\section{- Revive Time: Kaki Tree Project}

In 1996, Miyajima debuted his Revive Time: Kaki Tree Project, which at first glance appears to be a radical departure from his time-based art. ${ }^{66}$ The story behind the project is simple enough: Ebinuma Masayuki 海老沼 正幸, an arborist in Nagasaki, managed to foster back to health a persimmon tree (kaki tree) scarred from the atomic bombing of Nagasaki on 9 August $1945 \cdot{ }^{67}$ The tree began producing seedlings and, eventually, Ebinuma started to hand these out to children in Nagasaki to plant as symbols of peace. Miyajima met the arborist in 1995 when he was in Nagasaki for an exhibition, and, with his permission, began Revive Time: Kaki Tree Project in 1996 (modeled on Ebinuma's approach), with the first planting at the former Ryuhoku Elementary School. His aim was to decenter the role of the artist and allow each individual to make an artistic statement by planting a kaki sapling. Here, the kaki tree can be seen as a symbol of the continuity of life through horrific destruction, expressed in the cessation and rebirth of time in other projects such as Mega Death.

The project, which continues to this day with participating groups throughout Europe and Africa, bears clear resemblance to 7,00o Oaks, Joseph Beuys' contribution to the 1982 Documenta 7 in Kassel. ${ }^{68}$ Indeed,

65 Miyajima, Miyajima Tatsuo kaitai shinsho, p. 399

66 This assessment would be inaccurate as the artist has been practicing performance art since his tenure at Tokyo University of the Arts as an undergraduate student. In reality, it is a return for him to his origins in performance and socially engaged art.

67 I paraphrase here from information found on the project's website: "The Beginning," https://kakitreeproject.com/ english/?page_id $=5385$.

68 Joseph Beuys advanced the concept of "social sculpture" in the 1970s-of directly engaging society through art. This concept can be summed up in Beuys' famous line "everyone is an artist." One concrete example of his theory in action, which advocated the artist Hikosaka Naoyoshi 彦坂尚嘉 (b. 1946), one of Miyajima's most vocal critics (and, significantly, a member of Bikyōtō alongside Hori Kōsai), has called the work a second-rate imitation of Beuys' project. ${ }^{69}$ Significantly, Beuys visited Tokyo University of the Arts in 1984 while Miyajima was enrolled there, and participated in a debate with both students and faculty; he clearly influenced the young artist. Miyajima, however, has asserted a fundamental difference between his and Beuys' approaches:

It's been indicated that my ... concept is similar to Beuys' statement that "everyone is an artist." They may seem similar, but in Beuys' case, the existence of the "artist" is prized above everything else; for me, however, there is something "artistic" in everyone. I don't worship art. For me, humans are most important..$^{70}$

Elsewhere, he expands on this notion in more cryptic language:

Looking back it's painfully clear that Beuys was seeking a revolution from inside of capitalism. When he tried to do so by participating in the Green Party at the political level, however, it created a lot of friction. To avoid making the same mistake, I want to expand my work at the level of the human. ${ }^{71}$

It would be impossible to understand this notion of a "level of the human" that trumps the power of art or political participation (i.e., how is art-making or political participation not "human"?) without keeping in mind Ikeda's notion of "Buddhist humanism," that is, various individuals recognizing each other as humans first before considering their affiliations or abilities. $^{72}$ This humanism, as well as the image of Ikeda

for the democratization of creative expression, is this 7,000 Oaks project. It took five years for volunteers from the community to plant the trees throughout the city of Kassel as well as to place a basalt rock at the base of each tree.

69 “私なんかが、宮島達男氏の『柿の木プロジェタト』で一番気になった のは、ボイスの仕事の亜流だと言う事です。”http://www2a.biglobe. ne.jp/ yamaiku/honhon/lr/lr.hikosakaO2.htm.

70 Miyajima, "Wakatchairu kedo kandō dekiru," p. 155

71 Miyajima, Miyajima Tatsuo kaitai shinsho, pp. 355-56. This quote refers to the artist's founding of "Artists Summit Kyoto," but has bearing, I believe, on the Kaki Tree Project.

72 See Ikeda, "Buddhist Perspective on Conflict Resolution." 
as a peace builder, echoes rhetorically in the Kaki Tree Project, described (unsurprisingly) as "an art project through which people can learn about peace and the importance of life." 73 This message is extended in the project's goals, which represent an attempt to "revive" three disparate elements in the context of daily life: "Awareness of Peace" (in short, to "revive the dormant awareness of peace within people"), "The True Way to Live," and "Quality in Art."74 These aims are nebulous (how is it possible to determine a "true way to live" or "quality in art" in a radically fragmented, multicultural society?), and in general the project may seem quite naive in a contemporary art world dominated by postmodern critical discourse, in which artists are expected to "recognize and lay bare the hidden ideological devices which govern our routine lives without our knowledge." 75 Miyajima is largely uninterested in addressing the systemic economic problems or ideologies that prevent the development of worldwide peace, in confronting his own complicity in a highly speculative global art market fueled by fashion magnates and arms dealers, or using the "brand theory" that is so pervasive in the international art world to justify his work. Rather, through Kaki Tree Project, he takes it upon himself to teach people to appreciate their lives - and peace (if they have it) - by having them plant trees, as well as more indirectly to remember the horror of the atomic bombings. While the themes and aims of Kaki Tree Project are ambiguous enough that they could be taken in any number of ways (and many may criticize him on this count), I argue that the rhetoric supporting it - which seems quite vague without proper contextualization - is clearly recognizable to Gakkai members as the language of Ikeda Daisaku. As such, it serves as a symbol of collective identity in shiteifuni-an homage to Ikeda's own peace-building activities in the microcosm of art. Unlike Beuys, who appealed to a romantic image of the heroic artist, that is, self-mythology, to legitimate his pedagogic practice, Miyajima becomes a teacher in art precisely because Ikeda is his teacher.

73 Ikeda has met with heads of state and diplomats including Henry Kissinger, Zhou Enlai, and Nelson Mandela to discuss issues such as the proliferation of nuclear weapons, environmental degradation, and atrocities committed by Japan during World War II.

74 "Concepts," https://kakitreeproject.com/english/?page_id=5381.

75 Grant Kester, "The Device Laid Bare: On Some Limitations in Current Art Criticism," e-flux 50 (2013), https://www.e-flux.com/ journal/50/59990/the-device-laid-bare-on-some-limitations-incurrent-art-criticism/.

\section{Conclusion}

In 1996, the same year that he started Kaki Tree Project, Miyajima contributed an essay to The Flowering of Human Culture (Ningen bunka no hana hiraku 人間 文化の華ひらく), a collection of the abovementioned taikendan or conversion experiences regularly shared at Sōka Gakkai group meetings. In this essay, Miyajima touches on the centrality of daimoku (chanting the name of the Lotus Sutra) in his artistic practice, especially for giving him the intuitive ability to look at his works objectively. The essay closes with a powerful sentiment that symbolically frames, I argue, his entire career:

When I started thinking about art on the basis of eternal life, daimoku [namumyōhōrengekyō], Sōka Gakkai and its great leader, Teacher Ikeda, were there to show me how to judge my works.... Because we subscribe to this vision of eternal life, we can rigorously judge each moment. My mission as an artist is to render the accumulation of these judgments into powerful works of art. ${ }^{76}$

Here, the term "judgment" implies both a basis for aesthetic value (that is, the ability to view one's work objectively and assess its quality), but more importantly, a source of ethical certitude. I argue that Miyajima sees his ability as an artist as necessarily deriving from the latter-his art is first ethically and then aesthetically justified by the notion of eternal life that underlies it. In this collapsing of religious and artistic expression, one also sees the profound sense of community that the artist experiences through his affiliation with Sōka Gakkai (hence the plural first-person) and the way that this affiliation itself forms the basis of his art-his art serves as a collective symbol of the organization and its rhetoric.

Miyajima's art and underlying art concept prove hard to evaluate in contemporary art, a realm in which artists are still generally expected to form their own unique viewpoints and opinions that they convey to viewers through their work. Even if the ideal of autonomy has been increasingly challenged by the rise of socially engaged art and its study in the past twenty years,

76 Miyajima, "Hito toshite sosei shite kara hajimatta geijutsu e no michi," pp. 103-104. 
and despite the continuing diversification of contemporary art practices, artists who visibly associate with new religions like Sōka Gakkai are difficult to assess due to the persistent stigmatization of these religions in Japan. ${ }^{77}$ In spite of strong indications that their art represents a form of organized religious practice, their projects are assimilated into modernist visions of the heroic artist freely synthesizing various "spiritual" and religious interests into compelling works of art. The explicit links between Miyajima's art and the organization he belongs to may make some uncomfortable - indeed it could be said that he has elevated shōju 摂受 (Nichiren's term for nonaggressive proselytization) to the level of "fine art" by creating visually appealing and persuasive representations of Sōka Gakkai doctrine and practice through his work. Those inspired to look beyond its façade for a rationale will find it supported by a body of ideas (and occasionally concrete forms, for example, as in the abovementioned 2008 HOTO), shared by millions of believers worldwide.

I have attempted to argue in this article that what is most "unique" about Miyajima's project is the artist's meticulous re-creation of the system of values implied in Sōka Gakkai's doctrine and practice, both through Nichiren Buddhism and the worship of Ikeda Daisaku, inside the art world. Miyajima is first and foremost a member of Sōka Gakkai, and then an artist-it is clear that this affiliation has sustained his personal life while providing him with an expansive trove of content for his art. Furthermore, Miyajima's art and art concepts can be interpreted as substantiations of shiteifuni in contemporary Sōka Gakkai practice and doctrine: the representation of Miyajima's devotion to Ikeda Daisaku, and an attempt to embody this devotion through his life and work. The ideal of shiteifuni entails the idea that the disciple will never be able to live up to the mentor-Ikeda himself asserts this principle in his own unfailing devotion to his mentor, Toda Jōsei. Miyajima's relationship to Ikeda constantly renews him, it provides him with the courage to keep producing his art, to aspire to approach ever more closely to the ideals

77 The stigmatization (and at times persecution) of new religions has been prevalent in Japan since the prewar period (see, for example, the infamous suppression of the Shinto new religion Ōmotokyō 大本教 in 1935). In the postwar period, Sōka Gakkai was the most heavily smeared religious organization in the media until attention shifted to Aum Shinrikyo following the 1995 subway gas attack. See McLaughlin, "Did Aum Change Everything?" provided for him by his organization, ideals that form the bedrock of his identity: "Originality in the West comes from individualism, itself rooted in Christianity. Supporting us, starting with Teacher Ikeda, is a view of life in the Lotus Sutra that spans sanse 三世 [the three temporal worlds - past life, present life, future life]."78 For Miyajima, art is first and foremost a matter of association.

\section{Reference List}

Asai, Endō. “The 'Lotus Sutra' as the Core of Japanese Buddhism: Shifts in Representations of its Fundamental Principle." Trans. Jacqueline Stone. JJRS 41:1 (2014), pp. 45-64.

Buchloh, Benjamin. "Conceptual Art 1962-1969: From the Aesthetic of Administration to the Critique of Institutions." October 55 (1990), pp. 105-43.

Bywater, John. "Mediarena Govett-Brewster Art Gallery." Artforum 43:3 (2004), p. 239.

Chiba Shigeo 千葉成夫. Gendai bijutsu itsudatsushi: 1945-1985 現代美術逸脱史: 1945-1985. Shōbunsha, 1986.

Chilson, Clark. "Cultivating Charisma: Ikeda Daisaku’s Self Presentations and Transformational Leadership." Journal of Global Buddhism 15 (2014), pp. 65-78.

De Jongh, Karlyn. "Time in the Art of Roman Opalka, Tatsuo Miyajima, and Rene Rietmeyer." KronoScope 10:1-2 (2010), pp. 88-117.

Graham, Patricia. Faith and Power in Japanese Buddhist Art, 1600-2005. University of Hawai'i Press, 2007.

Groys, Boris. Art Power. MIT Press, 2008.

Groys, Boris. In the Flow. Brooklyn: Verso, 2016.

Hori Kōsai 堀浩哉. “Kōmeitō to Miyajima Tatsuo ni wa damasareruna” 公明党と宮島達男には騙されるな.”Aida あいた 66 (2001), p. 19.

Ikeda, Daisaku. "Buddhist Perspective on Conflict Resolution.” Religions 9 (2016), pp. 92-104.

Kinoshita Naoyuki 木下直之. Bijutsu to iu misemono: Aburae jaya no jidai 美術という見世物: 油絵茶屋の時代. Kōdansha Gakujutsu Bunko, 2010.

Kitazawa Noriaki 北澤憲昭. Kishida Ryūsei to Taishō avangyarudo 岸田劉生と大正アヴァンギャルド. Iwanami Shoten, 1993.

78 Miyajima, "Hito toshite sosei shite kara hajimatta geijutsu e no michi," p. 103. 
Kosuth, Joseph. Art after Philosophy and After: Collected Writings, 1966-199o. Ed. Gabriele Guercio. MIT Press, 1991.

Krauss, Rosalind. The Originality of the Avant-Garde and Other Modernist Myths. MIT Press, 1986.

Kunimoto, Namiko. “The Buddhist Hero." In Between Action and the Unknown: The Art of Kazuo Shiraga and Sadamasa Motonaga, ed. Gabriel Ritter, pp. 76-79. Dallas: Dallas Museum of Art, 2015.

Kuno Osamu 久野収 and Tsurumi Shunsuke 鶴見俊 輔. Gendai Nihon no shisō 現代日本の思想. Iwanami Shinsho, 1956.

McLaughlin, Levi. "Did Aum Change Everything? What Soka Gakkai Before, During, and After the Aum Shinrikyō Affair Tells Us About the Persistent 'Otherness' of New Religions in Japan.” JJRS 39:1 (2012), pp. 51-75.

McLaughlin, Levi. “Sōka Gakkai in Japan." In Handbook of Contemporary Japanese Religions, ed. Inken Prohl and John K. Nelson, pp. 269-307. Leiden; Boston: Brill, 2012. Miyajima Tatsuo 宮島達男. Geijutsuron 芸術論. Art Diver, 2017.

Miyajima Tatsuo 宮島達男. “Hito toshite sosei shite kara hajimatta geijutsu e no michi” 人として蘇生してから始ま つた芸術への道. In Ningen bunka no hana hiraku 人間 文化の華ひらく, ed. Sōka Gakkai Geijutsubu 創価学会芸 術部, pp. 89-104. Daisan Bunmeisha, 1996.

Miyajima Tatsuo 宮島達男. Miyajima Tatsuo kaitai shinsho 宮島達男解体新書. Akio Nagasawa Publishing, 2010.

Miyajima Tatsuo 宮島達男. “Sekai ga motomeru ningen no tetsugaku” 世界が求める人間の哲学. In Sōka Gakkai, shikisha wa kō miru 創価学会 識者はこう見る, ed. Ushio Henshūbu 潮編集部, pp. 129-34. Ushio Shuppansha, 2012.

Miyajima Tatsuo 宮島達男. “Wakatchairu kedo, kandō dekiru: Banjin no naka ni, sonna āto ga sonawatteiru” わ かっちゃいるけど、感動できる: 万人の中に、そんなアート が備わっている. Interviewed by Akimoto Yūji 秋元雄史. Bijutsu techō 美術手帖 908 (2008), pp. 141-155.

Shimada Hiromi 島田裕巳. Sōka Gakkai 創価学会. Shinchosha, 2004.

Shimazono Susumu 島㝨進. "Hotoke sunawachi seimei: Toda Jōsei” 仏すなわち生命: 戸田城聖. In vol. 1 of Gendai Nihon to bukkyō 現代日本と仏教, ed. Ikeda Eishun 池田英俊 and Kobayashi Takasuke 小林孝輔, pp. 312-17. Heibonsha, 2000.

Toda Jōsei 戸田城聖. Ningen kakumei (ge) 人間革命 (下). Seikyō Shinbunsha Shuppankyoku, 1993.

Tomii, Reiko. Radicalism in the Wilderness. MIT Press, 2016.
Tzou, Shwu-Huoy. "Cultural-Specific and International Influences on and Critical Perceptions of Five Asian Installation Artists: Gu Wenda, Yanagi Yukinori, Xu Bing, Miyajima Tatsuo, and Choi Jeong-Hwa." PhD dissertation, Texas Tech University, 2000.

Woo, Jung-Ah. "On Kawara's 'Date Paintings': Series of Horror and Boredom.” Art Journal 69:3 (2010), pp. 62-72. 